\title{
CORRELATION BETWEEN SEVERE MALNUTRITION AND PNEUMONIA AMONG UNDER-FIVE CHILDREN IN EAST JAVA
}

\author{
Korelasi Antara Jumlah Gizi Buruk dengan Jumlah Pneumonia Pada Balita di Jawa Timur
}

\section{Nurvita Ruwandasari}

Department of Epidemiology, Public Health Faculty, Universitas Airlangga, nurvita.ruwandasari2015@fkm.unair.ac.id

Corresponding Author: Nurvita Ruwandasari, nurvita.ruwandasari-2015@fkm.unair.ac.id, Department of Epidemiology, Public Health Faculty, Universitas Airlangga, Dr. Ir. H. Soekarno Street, Mulyorejo, Surabaya City, East Java, Indonesia, Postal Code 60115

\section{ARTICLE INFO}

Article History:

Received March, 9, 2019

Revised form April, $2^{\text {nd }}, 2019$

Accepted June, 25 ${ }^{\text {th }}, 2019$

Published online August, 30 ${ }^{\text {th }}, 2019$

\section{Keywords: \\ pneumonia; \\ severe malnutrition; \\ under-five children; \\ East Java}

\section{Kata Kunci:}

pneumonia;

gizi buruk;

balita;

Jawa Timur

\begin{abstract}
Background: East Java Province is the second highest province with pneumonia cases among under-five children totalling $69.17 \%$ of all the discovery target of pneumonia cases in 2016. One factor causing pneumonia is severe malnutrition (nutritional status with body weight index according to age which is equal to Zscore < -3 SD). Purpose: This study is aimed at analyzing the correlation between severe malnutrition number and pneumonia cases among under five-year old children per regency/city in East Java. Methods: This type of research was an analytical observational study using a population correlational design. This study used the total population of the number of pneumonia cases and severe malnutrition cases among under five-year old children from all regencies/cities in East Java in 2015-2017. The test used was the Kolmogorov-Smirnov test as a data normality test and Spearman's correlation test to determine whether there was a correlation. Results: This study showed a positive correlation between the number of severe malnutrition and the number of pneumonia cases among under five-year old children per regency/city in East Java $(\mathrm{p}=<0.01, \mathrm{p}<0.05)$ with a moderate correlation (Spearman's correlation $=0.41$ ). Conclusion: The number of severe malnutrition cases has a positive correlation with the number of pneumonia cases among under five-year old children per regency/city in East Java in 2015-2017. Effective countermeasures of severe malnutrition are likely to help reduce the number of pneumonia cases among children under five years of age per regency/city in East Java.
\end{abstract}

C2019 Jurnal Berkala Epidemiologi. Published by Universitas Airlangga.

This is an open access article under CC-BY-SA license (https://creativecommons.org/licenses/by-sa/4.0/)

\section{ABSTRAK}

Latar Belakang: Provinsi Jawa Timur merupakan provinsi dengan kasus kedua tertinggi pneumonia pada balita sebesar 69,17\% dari target penemuan pneumonia pada balita tahun 2016. Salah satu faktor yang menyebabkan pneumonia adalah gizi buruk (status gizi dengan indeks berat badan menurut umur yaitu $Z$ score < $-3 S D$ ).

Tujuan: Penelitian ini memiliki tujuan untuk menganalisis korelasi 
antara jumlah gizi buruk balita dengan jumlah pneumonia balita per kabupaten/kota di Jawa Timur tahun 2015-2017. Metode: Jenis penelitian ini adalah observasional analitik dengan rancang bangun menggunakan studi korelasi populasi. Penelitian ini menggunakan total populasi dengan populasi penelitian adalah jumlah kasus pneumonia balita dan gizi buruk balita dari seluruh kabupaten/kota di Jawa Timur tahun 2015-2017. Uji yang digunakan yakni uji Kolmogorov Smirnov sebagai uji normalitas data dan uji korelasi Spearman untuk mengetahui ada tidaknya korelasi. Hasil: Penelitian ini menunjukkan hasil korelasi positif antara jumlah gizi buruk balita terhadap jumlah pneumonia balita per kabupaten/kota di Jawa Timur tahun 2015-2017 ( $p=<0,01, p<0,05)$ dengan kuat korelasi sedang (Spearman correlation $=0,41)$. Kesimpulan: Jumlah gizi buruk balita berkorelasi positif dengan jumlah pneumonia balita per kabupaten/kota di Jawa Timur pada tahun 2015-2017. Penanggulangan gizi buruk yang efektif kemungkinan akan membantu menurunkan jumlah kasus pneumonia pada balita per kabupaten/kota di Jawa Timur.

(C2019 Jurnal Berkala Epidemiologi. Penerbit Universitas Airlangga. Jurnal ini dapat diakses secara terbuka dan memiliki lisensi CC-BY-SA (https://creativecommons.org/licenses/by-sa/4.0/)

\section{INTRODUCTION}

Pneumonia is very susceptible to childrenwho are under five years of age, in which the majority of cases are caused by the Streptococcus pneumoniae bacteria (Gritly et al., 2018). Parents who do not understand the symptoms and signs of pneumonia correctly will consider the disease as a common cold, so they usually only give perfunctory treatment to their children. Typical symptoms of pneumonia are rapid breathing and shortness of breath (Mading \& Adyana, 2014). Under five-year old children who suffer from pneumonia when treated in the wrong way or handled late will aggravate the disease and lead to death. Most deaths from pneumonia occur at the age of infants and children under five years of age (Susanti, 2018).

Every year around 12 million children die before the age of five and the majority occur in the first year of life. Seven of the ten deaths were caused by acute respiratory infections, most of which were pneumonia. About 60-100 under-five deaths per 1,000 live births occur mostly in developing countries. One fifth of these deaths are caused by pneumonia (Gritly et al., 2018). Two under-five mortalities was caused by pneumonia every minute. Pneumonia resulted in the deaths of as many as 920,000 children in 2015 (Watkins et al., 2016).

Period prevalence of pneumonia per 1000 under-five children in a period of $\leq 1$ month in
Indonesia in 2013 based on diagnosis and symptoms was $18.50 \%$ and the percentage of children under five who were treated was only $1.60 \%$. The period prevalence of under-five children with pneumonia in East Java Province in 2013 based on diagnosis and symptoms was 15.80 $\%$. The highest period prevalence in the 36-47 months age group was $18.20 \%$, in the lowest quintile the ownership index was $23.40 \%$, and in the rural area it was $19.30 \%$ (Kemenkes RI, 2013).

The number of under-five children with pneumonia in Indonesia in 2016 was 503,738 or $57.84 \%$ of the target of finding under-five children with pneumonia cases. Under-five children with pneumonia cases in East Java Province amounted to 90,256 or as much as $69.17 \%$ of the target of under-five children with pneumonia case findings. East Java ranks the second highest in cases of under-five children with pneumonia in Indonesia, including the top 10 provinces with the highest percentage of coverage of pneumonia findings and is above the coverage of under-five children with pneumonia case findings in Indonesia (Ministry of Health RI, 2017).

The findings of under-five children with pneumonia recorded and handled in 2015 in East Java were 99,190 cases, increasing in 2016 to 102,712 cases, and decreasing in 2017 to 86,358 cases. These high numbers of pneumonia cases need serious attention because not all cases have been recorded and reported by health facilities, 
especially by independently practicing doctors, private hospitals, and private clinics (East Java Provincial Health Office, 2018).

The risk of pneumonia in under-five children is influenced by the nutritional status of the children, which is malnutrition. Under-five children with poor nutritional status have a weak body defense system allowing their bodies to be susceptible to infectious diseases. Malnutrition is a nutritional disorder that can adversely affect the health of under-five children. If it is not handled properly it will hinder the growth of children (Wahyudi, 2015).

Nearly 20 million children in the world suffer severe malnutrition and \pm 1 million of them die every year. There are more than 12 million children in Asia who suffer severe malnutrition, including in Afghanistan, Bangladesh, and Yemen reaching 0.60 million in each of those countries, in India as much as 8 million, in Indonesia as much as 1.20 million and in Pakistan as much as 1.40 million (Ahmed et al., 2014).

Severe malnutrition in under-five children in 2013 in Indonesia was $5.70 \%$ of the whole population of under-fives. This prevalence was greater when it was compared to those of 2007 and 2010, which were $5.40 \%$ and $4.90 \%$, respectively. Meanwhile, severe malnutrition in East Java was $4.80 \%$ in 2007 and climbed slightly to $4.90 \%$ in 2013. The severe malnutrition prevalence of under-five children in East Java was the highest in the age group of 24-35 months reaching 6\%, in the group of family heads without any educational backgrounds at $6.90 \%$, in the unemployed group at $5.50 \%$, in the lower middle wealth quintile index at $7.60 \%$, and in rural areas at $5.70 \%$ (Ministry of Health RI, 2013).

The findings of under-five children with severe malnutrition experienced a decline during 2015-2017 in East Java. There were 5, 663 cases of severe malnutrition in under-five children in 2016, decreasing from 2015 with a total of 6,015 cases, and it decreased again in 2017 with 4,716 cases only. This decline in the number of cases was likely due to nutrition monitoring training in local government health centers (East Java Provincial Health Office, 2018).

Under-five children with poor nutritional status have a higher risk of contracting pneumonia. Based on the result of the study by Frini, Rahman, \& Herman (2018) it was revealed that children under five with poor or less nutritional status had a risk of 3.80 times contracting pneumonia compared to under-five children with normal nutritional status. Poor nutritional status causes damage to the body's defense system, which is used to fight microorganisms, so it will be easy to get pneumonia. The severity of pneumonia also increases with increasing severity of malnutrition. The incidence of pneumonia in severe malnutrition Level 4 or malnutrition in under-five children was found to be $72 \%$. The presence of local and systemic immune disorders in young children with poor nutrition can increase the severity of pneumonia (Arpitha, Rehman, \& Ashwitha, 2014). This study aims to analyze the correlation between the number of under-five children with severe malnutrition and the number of under-five children with pneumonia per regency/city in East Java in 2015-2017.

\section{METHODS}

This study was an analytical observational study using a population correlation design. The unit of analysis in this study is the aggregate data from each regency/city in East Java. This study uses the total population of the number of cases of under-five children with pneumonia and underfive children with severe malnutrition from all regencies/cities in East Java in 2015-2017. The data used was in the form of secondary data originating from the East Java Health Profiles produced by the East Java Provincial Health Office. The research variables were cases of under-five children with pneumonia in each regency/city in East Java as the dependent variable, and severe malnutrition in under-five children in each regency/city in East Java as the independent variable.

Diagnosis of pneumonia is carried out by medical personnel at local government health centers (Puskesmas) and other health facilities. Severe malnutrition is the result of nutritional status through measurement of body weight per age $(\mathrm{BB} / \mathrm{U})$ with a Z-score value of $<-3.0 \mathrm{SD}$. Diagnosis of severe malnutrition is carried out by nutritionists at these local government health centers and other health facilities. The data analysis used Spearman's test by first doing the Kolmogorov Smirnov test to perform data normality.

\section{RESULTS}

Description of Pneumonia in Under-five Children and Under-five Children with Severe Malnutrition in East Java in 2015-2017

The number of pneumonia cases among under-five children in East Java Province over a 
period of three years (2015-2017) fluctuated. The number of under-five children with pneumonia cases increased in 2016 to as many as 3,522 cases and in 2017 it decreased by 16,354 cases (Table $1)$.

Jember Regency was the regency with the highest cases of pneumonia among children under five in 2015 and Sidoarjo Regency was the highest in both 2016 and 2017. The regencies with the five highest incidences in East Java for three years (2015-2017) were Jember, Gresik, Sidoarjo, and Mojokerto. Jember, Gresik, Bojonegoro experienced a decline in cases for three years (2015-2017), while Sidoarjo experienced an increase in 2017 (Table 2).

\section{Table 1}

Number of Pneumonia Cases on Under-Five Children in East Java Province in 2015-2017

\begin{tabular}{cr}
\hline \multicolumn{1}{c}{ Variable } & Total \\
\hline Year & \\
2015 & 99,190 \\
2016 & 102,712 \\
2017 & 86,358 \\
\hline
\end{tabular}

Table 2

List of Regencies/Cities in East Java Province with the Highest Case of Under-Five Children Pneumonia in 2015-2017

\begin{tabular}{clr}
\hline \multicolumn{1}{c}{ Year } & Regencies/Cities & \multicolumn{1}{c}{ Jumlah } \\
\hline $\mathbf{2 0 1 5}$ & Kab. Jember & 9,066 \\
& Kab. Gresik & 8,536 \\
& Kab. Sidoarjo & 8,834 \\
& Kab. Bojonegoro & 8,242 \\
$\mathbf{2 0 1 6}$ & Kab. Mojokerto & 5,708 \\
& Kab. Sidoarjo & 8,411 \\
& Kab. Jember & 8,065 \\
& Kab. Gresik & 7,344 \\
& Kab. Mojokerto & 5,758 \\
$\mathbf{2 0 1 7}$ & Kab. Bojonegoro & 5,576 \\
& Kab. Sidoarjo & 8,747 \\
& Kab. Gresik & 6,842 \\
& Kab. Mojokerto & 4,736 \\
& Kab. Jember & 4,643 \\
& Kota Surabaya & 4,127 \\
\hline
\end{tabular}

The number of cases of under-five children with severe malnutrition in East Java Province over a period of three years (2015-2017) kept decreasing. In 2016 there was a decline of 352 cases from the previous year, and in 2017 there was a decline of 947 cases (Table 3).

Banyuwangi Regency is the regency with the highest cases of under-five children with severe malnutrition for three years (2015-2017), while Tuban Regency is one of the five regencies/cities with the highest cases for three years (2015-2017). Nonetheless, Bayuwangi, Tuban, Lumajang, Nganjuk and Probolinggo regencies experienced a decline in cases over these three years (Table 4).

Table 3

Number of Severe Malnutrition Cases in UnderFive Children in East Java Province 2015-2017

\begin{tabular}{|c|c|}
\hline Variable & Frequency (n) \\
\hline Tahun & \\
\hline 2015 & 6.015 \\
\hline 2016 & 5.663 \\
\hline 2017 & 4.716 \\
\hline
\end{tabular}

Table 4

List of Regencies/Cities in East Java Province with the Highest Cases of Under-Five Children with Severe Malnutrition in 2015-2017

\begin{tabular}{clr}
\hline Year & Regencies/Cities & Total \\
\hline $\mathbf{2 0 1 5}$ & Kab. Banyuwangi & 658 \\
& Kab. Lumajang & 616 \\
& Kab. Nganjuk & 574 \\
& Kab. Probolinggo & 398 \\
$\mathbf{2 0 1 6}$ & Kab. Tuban & 351 \\
& Kab. Banyuwangi & 567 \\
& Kab. Lumajang & 494 \\
& Kab. Nganjuk & 378 \\
$\mathbf{2 0 1 7}$ & Kab. Tuban & 337 \\
& Kab. Probolinggo & 304 \\
& Kab. Banyuwangi & 526 \\
& Kab. Magetan & 332 \\
& Kab. Tuban & 331 \\
& Kab. Bondowoso & 308 \\
& Kota Surabaya & 278 \\
\hline
\end{tabular}

Analysis of Correlation between the Number of Severe Malnutrition Cases among Under-five Children with the Number of Under-five Children with Pneumonia cases per Regency/City in East Java in 2015-2017

The results of the Kolmogorov-Smirnov test for the variable of under-five children with severe malnutrition showed a significance value of $<0.01$ and the variable of pneumonia among under-five children with a significance of 0.05 . The variable of under-five children with severe malnutrition could be categorized as data that was not normally distributed because the results were $<\alpha$ with $\alpha=$ 0.05 , so the Spearman's correlation test could be continued (Table 5).

The results of the analysis with the Spearman's test showed a significance $<0.01$ with 
$\alpha=0.05(\mathrm{p}<\alpha)$ which means that there is a correlation between the number of under-five children with severe malnutrition and the number of under-five children with pneumonia cases per regency/city in East Java. The strength of the correlation between the two variables is 0.41 , which means that the moderate correlation between them has the direction of positive correlation (Table 5).

\section{Table 5}

Normality and Spearman's Correlation Test between Severe Malnutrition in Under-five Children and Pneumonia Cases

\begin{tabular}{lr}
\hline \multicolumn{1}{c}{ Category } & \multicolumn{1}{c}{ Results } \\
\hline $\begin{array}{l}\text { Severe Malnutrition among } \\
\text { Under-five Children }\end{array}$ & \\
Kolmogorov-Smirnov Z & 1.77 \\
Asymp. Sig.(2-tailed) & $<0.01$ \\
Under-five Children with & \\
Pneumonia & \\
Kolmogorov-Smirnov Z & 1.35 \\
Asymp. Sig.(2-tailed) & 0.05 \\
Correlation Test & \\
Spearman correlation & 0.41 \\
Sig. (2-tailed) & $<0.01$ \\
\hline
\end{tabular}

The direction of correlation between the number of severe malnutrition cases in under-five children with the number of pneumonia cases in under-five children per regency/city in East Java in 2015-2017 formed a straight line, indicating there was a linear relationship which showed a positive correlation direction, so it can be interpreted that when there is an increase in the number of cases of under-five children with severe malnutrition, the number of pneumonia cases in under-five children also increases, or vice versa the lower the severe malnutrition cases among under-five children are, the lower the cases of under-five children with pneumonia are (Figure 1).

\section{DISCUSSION}

\section{Description of Pneumonia cases in Under-Five Children and Under-Five Children with Severe Malnutrition in East Java in 2015-2017}

The spread of pneumonia cases in children with the five highest cases in East Java for three years (2015-2017) generally occurred in adjacent areas. These adjacent areas, namely Gresik Regency, Sidoarjo Regency, Mojokerto and Surabaya City were only included in the five highest cases of under-five children with pneumonia in 2017. Other regencies with high cases of pneumonia among under-five children are Bojonegoro and Jember.

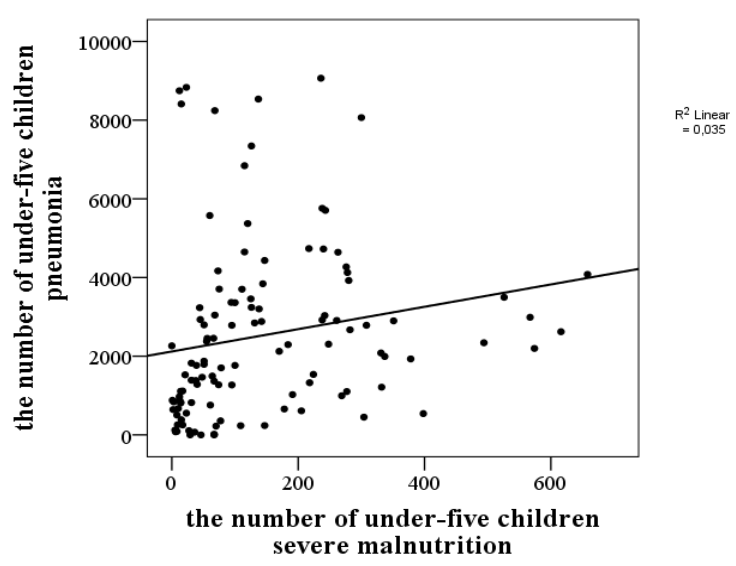

Figure 1. Correlation between the number of severe malnutrition cases and the number of pneumonia cases in under-five children per regency/city in East Java in 2015-2017

Adjacent areas will have an influence on each other, which can increase the risk of transmission of pneumonia than areas that are a distance apart. The location of adjacent areas tends to have almost the same geographical and habitual aspects, allowing pneumonia cases in these areas to be of almost the same in number. Under-five children who suffer from pneumonia can definitely be affected by the condition of the surrounding environment. In urban areas, houses are usually relatively close to each other, there are many more occupants, and there is less air ventilation. In contrast to urban areas, rural areas have healthier housing conditions and cleaner air, even though there are still houses with dirt floors. These conditions can cause the occurrence of pneumonia in each region (Susanti, 2018).

The spread of disease is influenced by the population density in an area because the transmission of bacteria and viruses that cause pneumonia is more easily and quickly transmitted through breathing. The denser the population is, the greater the chances of contact with pneumonia sufferers are. Areas with houses that are close to each other will have limited movement so clean air needs are not met. This raises the risk of pneumonia transmission (Syani \& Raharjo, 2015). A study by Anwar \& Dharmayanti (2014) revealed that dense dwellings with a lot of children under five pose the risk of pneumonia 1.20 times greater than spacious dwellings.

Maternal knowledge is also another factor that can affect the severe malnutrition status of 
under-five children. Knowledge is directly proportional to education which will affect mothers in seeking, understanding, accepting, and encouraging the implementation of information in the form of behavior. Mothers who have knowledge of proper nutrition for children under five will better prepare and manage this nutrition so as to minimize the possibility of severe malnutrition in their children, while mothers who lack knowledge about the appropriate nutrition for children under five can increase the risk of having their children to suffer severe malnutrition (Wahyudi, 2015). Education affects the actions of mothers in doing prevention, health care and treatment. Mothers with low education tend to consider pneumonia as a common cold disease (Darmawati, Sunarsih, \& Trisnaini, 2016). The results of Aldriana (2015) research stated that mothers of children under five with low education are at risk six times more likely to have their children suffer from pneumonia than mothers of children under five who have higher levels of education. This is due to the lack of mother's knowledge about disease and preventive efforts.

Meanwhile, the socio-economic factor that affects the nutritional status of children is family income. The larger the income that parents have will make it easier for them to obtain diverse and nutritious foods for their under-five children so that they can get enough energy intake and avoid severe malnutrition (Oktavia, Widajanti, \& Aruben, 2017). Parents who have low income cannot afford to full meal so they cannot meet the required energy intake for their under-five children who will eventually be vulnerable to severe malnutrition (Wahyudi, 2015). Low income is a factor in the occurrence of pneumonia among under-five children. $65 \%$ of cases of under-five pneumonia occurred in families with a lower economic level (Gritly et al., 2018). Lower middle economic status is at risk of pneumonia in underfive children 1.40 times greater than middle to upper economic status (Anwar \& Dharmayanti, 2014). Severe malnutrition does not only occur in rural areas but can also occur in urban areas. This is evidenced by the entry of Surabaya City as an area with the fifth highest number of severe malnutrition cases in East Java in 2017. This is apparently inseparable from the way parents treat their under-five children (East Java Provincial Health Office, 2018).

One of the factors that influences severe malnutrition is wrong parenting. Parents play an important role in their children's growth through proper, adequate feeding and health maintenance
(Pratiwi, Masrul, \& Yerizel, 2016). Parents who are busy working oftentimes entrust their underfive children to their grandmothers or sitters. People who do not have enough knowledge and understanding about their under-five children's nutrition may only give their children perfunctory food which does not contain the necessary nutrients for their optimal growth.. On the other hand, caregivers of children who pay attention to the provision of under-five children's nutrition according to what is needed, the nutritional status of these children will be in accordance to their proper upbringing patterns. There are also cases where parents actually have followed proper parenting but their under-five children still have poor nutritional status. This can be caused by under-five children who do not like to consume a variety of foods that are diverse or have difficulties to eat (Manumbalang, Rompas, \& Bataha, 2017). The results of a study by Munaroh (2015) stated that parenting styles that influence nutritional status are in the form of giving enough love, attention and comfort to encourage good growth of their under-five children.

Another influencing factor for severe malnutrition is exclusive breastfeeding. Exclusive breastfeeding can prevent children from getting severe malnutrition. Children who are given exclusive breastfeeding have much better growth than those who are not. Exclusive breastfeeding is given until the age of six months and then continued until the age of two years accompanied by MP-ASI (weaning food). Breast milk is very suitable with the baby's digestive system since the nutrients it contains can be absorbed more quickly. This is different if the infants are given formula milk or weaning food before the age of six months (Kartiningrum, 2015). The risk of suffering from pneumonia in under-five children who are not given exclusive breastfeeding is 3.03 times greater compared to those with exclusive breastfeeding (Frini, Rahman, \& Herman, 2018). The results of research by Aldriana (2015) showed that the risk of pneumonia is 14 times higher in under-five children without exclusive breastfeeding. Underfive children with exclusive breastfeeding have optimal immunity because breast milk, in addition to having a complete nutritional content, also contains antibodies or immune substances so that children are not easily susceptible to infectious diseases (Kartiningrum, 2015). Under-five children's immune system also depends on the duration of breastfeeding (ASI) (Aldriana, 2015). The results of the study by Yudiastuti, Sawitri, \& Wirawan (2015) stated that the duration of 
exclusive breastfeeding that was less than two months could result in 5.20 times higher risk of under-five children developing pneumonia compared to the duration of more than two months.

The factor of nutritional intake in infants is also very important to note because it affects the severe malnutrition of children under five. The growth of children under the age of five is influenced directly by food quantity, nutrient content in food, and food hygiene. According to the study by Oktavia et al (2017) $85 \%$ of underfive children with severe malnutrition status were found to lack energy and protein intake, so it can be concluded that nutritional status is influenced by energy and protein intake. Consumption of energy and protein is a direct factor in determining whether the nutritional status of children under five years of age is sufficient or not. Energy and protein deficiencies that occur progressively cause mucosal damage, decreasing resistance to colonization, and invasion of pathogenic germs. Lowered immunity that is followed by mucosal damage can affect the body's defense system, making the body more easily infected with infectious diseases, such as pneumonia (Rahim, 2014).

The spread of five highest severe malnutrition cases in under-five children in East Java for three years (2015-2017) was almost evenly distributed in various regencies/cities throughout the province. Banyuwangi became the area with the highest cases of severe malnutrition in under-five children for three years (2015-2017). The distribution of severe malnutrition in the province with the five highest cases is mostly concentrated in the socalled horseshoe areas, namely Lumajang, Probolinggo, and Bondowoso. Other areas with high cases of malnutrition in under-five children were Nganjuk, Tuban, Magetan, and Surabaya City (East Java Provincial Health Office, 2018).

\section{Analysis of Correlation of the Number of Severe Malnutrition Cases in Under-Five Children with the Number of Pneumonia Cases Among Under-Five Children Per Regency/City in East Java in 2015-2017}

The correlation results showed that the higher the cases of under-five children with severe malnutrition were, the higher the cases of underfive children with pneumonia were, or vice versa the lower the cases of under-five children with severe malnutrition were, the lower the incidences of under-five with pneumonia were. Due to the existence of a positive correlation between the number of cases of under-five children with severe malnutrition and the number of cases of under-five children with pneumonia per regency/city in East Java, the effective efforts to overcome severe malnutrition will contribute to reducing the number of cases of pneumonia in under-five children per regency/city in East Java. Preventive programs for severe malnutrition among underfive children cover things such as intensifying the discovery of under-five children with severe malnutrition through regular weighing, supplementary feeding, care for under-five children's nutrition, community nutrition education, and capacity building for nutritionists. These efforts were expected to help reduce cases of under-five children with severe malnutrition and the possibility of a correlation in the decline in the number of cases of pneumonia among under-five children (East Java Provincial Health Office, 2016).

A study by Oktavia et al (2017) stated that there is a relationship between nutritional status of children with infectious diseases. Research conducted by Wicaksono (2017) in the work area of Puskesmas (Public Health Center) Gane Luar, South Halmahera in July-December 2014 revealed that nutritional status was significantly associated with pneumonia in under-five children $(p=0.01)$. According to Rahman, Khatun, Azhar, Rahman, \& Hossain (2014) severe malnutrition can affect under-five children in contracting pneumonia. The results of the study by Frini, Rahman, \& Herman (2018) stated that nutritional status was associated with incidences of pneumonia among under-five children at Kamonji Health Center $(\mathrm{OR}=3.85$; $95 \% \mathrm{CI}=2.18<\mathrm{OR}<6.81$ ). The risk of under-five children who have severe malnutrition or malnutrition to suffer from pneumonia is 3.85 times greater than under-five children with normal nutrition.

The research conducted by Piliang \& Filda (2018) in mothers who have under-five children at the Umban Sari Pekanbaru Health Center for the period of October to December 2015 found that almost all of the 16 children under five they studied who experienced severe malnutrition had pneumonia, or $93.80 \%$ (15 children), and only $6.20 \%$ or one child who did not have pneumonia. The results of this study concluded that severe malnutrition had a significant relationship with the incidence of pneumonia among under-five children.

Nutrition can affect the development of the immune system of the human body and the emergence of diseases. Malnutrition will increase 
the risk of death from pneumonia by up to four times greater than normal nutritional status. Deficiencies of micronutrients such as zinc and Vitamin D will also affect the decrease in the body's immune system making it prone to transmission of pneumonia (Watkins et al., 2016).

The body that has severe malnutrition or malnutrition has fewer immunity mediator cells, weaker complement system, and less IgA secretion making its humoral immunity become more vulnerable. There is a disruption of epithelial regeneration in the respiratory tract. The thymus gland and tonsils become atrophic, so the number of t-lymphocytes decreases gradually. The mechanism of cellular immunity deficiency will make the infectious process easier (Wicaksono, 2017).

Under-five children who suffer severe malnutrition are at risk of developing pneumonia because their body defense system becomes weak or decreases, so the body will be susceptible to disease. Children under five are at a vulnerable age period because the immune system in their bodies has not yet fully formed, so they are more at risk of getting an infectious disease if there is only a little intake of nutrients consumed (Monita, Yani, \& Lestari, 2015). Other factors that can also cause pneumonia in children under-five are immunization status, low birth weight, exposure to cigarette smoke, physical conditions of the home environment, and so on (Aldriana, 2015; Suryani, Hadisaputro, \& Zain, 2018).

\section{CONCLUSION}

There is a correlation between the number of cases of under-five children with severe malnutrition with the number of cases of underfive children with pneumonia per regency/city in East Java in 2015-2017 and a strong moderate correlation. The correlation direction is positive which means that if there is an increase in the number of cases of under-five children with severe malnutrition, the number of cases of under-five children with pneumonia will also increase, or vice versa. The existence of this correlation implies that the program to overcome severe malnutrition in under-five children should continue to be improved effectively in order to reduce cases of severe malnutrition so that there is a possibility that there will also be a decrease in the number of cases of under-five children with pneumonia per regency/city in East Java.

\section{ACKNOWLEDGMENTS}

Special thanks to the East Java Provincial Health Office as the provider of data used in this study and to all the financially assisting parties

\section{REFERENCES}

Ahmed, T., Hossain, M., Mahfuz, M., Choudhury, N., Hossain, M. M., Bhandari, N., ... Bhutta, Z. (2014). Severe acute malnutrition in Asia. Food Nutrition Bulletin, 35(2), 14-26. https://doi.org/10.1177/15648265140352S10 3

Aldriana, N. (2015). Factors Associated with pneumonia in children under five in the Region Rambah Samo Health Centers in 2014. Jurnal Maternity and Neonatal, 1(6), 262-266.

Anwar, A., \& Dharmayanti, I. (2014). Pneumonia among children under five years of age in Indonesia. Jurnal Kesehatan Masyarakat Nasional, 8(8), 359-365.

Arpitha, G., Rehman, M. A., \& Ashwitha, G. (2014). Effect of severity of malnutrition on pneumonia in children aged $2 \mathrm{M}-5 \mathrm{Y}$ at a tertiary care center in Khammam, Andhra Pradesh: a clinical study. Scholars Journal of Applied Medical Sciences (SJAMS), 2(6E), 3199-3203.

Darmawati, A. T., Sunarsih, E., \& Trisnaini, I. (2016). Relationship between physical housing condition and behavioral with pneumonia incidence in under five year old children in the working area of Public Health Center Yosomulyo Metro City. Jurnal Ilmu Kesehatan Masyarakat, 7(1), 6-13. https://doi.org/https://doi.org/10.26553/jikm. 2016.7.1.6-13

East Java Provincial Health Office. (2016). East Java Provincial health profile in 2015. East Java Provincial Health Office. Surabaya City.

East Java Provincial Health Office (2018). East Java Provincial health profile in 2017. East Java Provincial Health Office. Surabaya City.

Frini, M., Rahman, N., \& Herman. (2018). Risk factors of pneumonia in children under five in the working area of the Palu City Kamonji Health Center (Puskermas). Preventif: Jurnal Kesehatan Masyarakat, 9(1), 34-37.

Gritly, S. M. O., Osman Elamin, M., Rahimtullah, H., Ali, A. Y. H., Dhiblaw, A., Mohamed, E. A., \& Adetunji, H. A. (2018). Risk factors of pneumonia among children under 5 years at a pediatric hospital in Sudan. International 
Journal of Medical Research \& Health Sciences, 7(4), 60-68.

Kartiningrum, E. D. (2015). Risk factors for the incidence of malnutrition in infants in Gayaman Village, Mojoanyar District, Mojokerto. Hospital Majapahit, 7(2), 1-11.

Mading, M., \& Adyana, N. W. (2014). Nutritional status and immunization as determinants of toddler pneumonia in East Nusa Tenggara Province. Buletin Penelitian Sistem Kesehatan, 17(4), 407-414.

Manumbalang, S. T., Rompas, S., \& Bataha, Y. B. (2017). The relationship between parenting and nutritional status in children is primarily a child in Pulutan District, Talaud Regency. E-Journal Keperawatan (e-Kp), 5(2), 1-8.

Ministry of Health RI. (2013). National basic health research (Riskesdas) 2013. Ministry of Health RI. Jakarta.

Ministry of Health RI. (2017). Indonesia's health profile in 2016. Ministry of Health RI. Jakarta.

Monita, O., Yani, F. F., \& Lestari, Y. (2015). Profile of community pneumonia patients in the pediatric department of RSUP Dr. M. Dajmil Padang, West Sumatra. Jurnal Kesehatan Andalas, 4(1), 218-226.

Munaroh, S. (2015). Parenting affects the nutritional status of toddlers. Jurnal Keperawatan, 6(1), 44-50.

Oktavia, S., Widajanti, L., \& Aruben, R. (2017). Factors related to malnutrition status in children under five in Semarang City in 2017 (study at the Banyumanik Nutrition Recovery House in Semarang City). Jurnal Kesehatan Masyarakat (e-Journal), 5(3), 186-192.

Piliang, N. S., \& Filda, M. (2018). Relationship of nutritional status with toddler pneumonia in Puskesmas Umban Sari Pekanbaru in 2016. Jurnal Endurance, 3(2), 325-329. https://doi.org/10.22216/jen.v3i2.2837

Pratiwi, T. D., Masrul, \& Yerizel, E. (2016). The relationship between mother's parenting and the nutritional status of children under five in the working area of Belimbing public health center (Puskesmas) in Padang. Jurnal Kesehatan Andalas, 5(3), 661-665. https://doi.org/10.1080/19325037.2013.7677 34

Rahim, F. (2014). Risk factors of underweight toddlers aged 7-59 months. Jurnal Kesehatan Masyarakat, 9(2), 115-121.

Rahman, S., Khatun, A., Azhar, B., Rahman, H., \& Hossain, S. (2014). A study on the relationship between nutritional status and prevalence of pneumonia and diarrhoea among preschool children in Kushtia. Pediatrics Research International Journal, (May), 1-10. https://doi.org/10.5171/2014.805309

Suryani, S., Hadisaputro, S., \& Zain, S. (2018). Environmental risk factors associated with the incidence of pneumonia in toddlers (study in the working area of Bengkulu City Health Office). Higiene, 4(1), 26-31.

Susanti, S. (2018). Pneumonia's mapping in East Java Province. Jurnal Biometrika dan Kependudukan, 5(2), 117-124. https://doi.org/10.20473/jbk.v5i2.2016.117124

Syani, F. El, \& Raharjo, M. (2015). The relationship of environmental risk factors to the incidence of toddler pneumonia with a spatial analysis approach in North Semarang District. Jurnal Kesehatan Masyarakat, 3(3), 732-744.

Wahyudi, B. (2015). Analysis of factors related to cases of malnutrition in children under five. Jurnal Pediomaternal, 3(1), 83-91.

Watkins, K., Wright, S., Le Nestour, A., Mathieson, K., Alfaiate, J., Leigh, C., ... Ahmar, S. (2016). Fighting for breath: a call to action on childhood pneumonia (1st ed.). Save The Children. London. https://doi.org/10.21313/hawaii/9780824836 825.001 .0001

Wicaksono, H. (2017). Nutritional status affects incidence of pneumonia in underfives. Folia Medica Indonesiana, 51(4), 285-291. https://doi.org/10.20473/fmi.v51i4.2861

Yudiastuti, N. K. E., Sawitri, A. A. S., \& Wirawan, D. N. (2015). Duration of exclusive breastfeeding, housing, and environmental conditions as risk factors of pneumonia among under-five children at Public Health Center II South Denpasar. Public Health and Preventive Medicine Archive, 3(2), 92-98. https://doi.org/10.15562/phpma.v3i2.98 